\title{
Article
}

\section{Love, rights and solidarity: studying children's participation using Honneth's theory of recognition}

Thomas, Nigel

Available at http://clok.uclan.ac.uk/3094/

Thomas, Nigel ORCID: 0000-0002-5310-9144 (2012) Love, rights and solidarity: studying children's participation using Honneth's theory of recognition. Childhood, 19 (4). pp. 453-466. ISSN 0907-5682

It is advisable to refer to the publisher's version if you intend to cite from the work. http://dx.doi.org/10.1177/0907568211434604

For more information about UCLan's research in this area go to http://www.uclan.ac.uk/researchgroups/ and search for < name of research Group>.

For information about Research generally at UCLan please go to http://www.uclan.ac.uk/research/

All outputs in CLoK are protected by Intellectual Property Rights law, including Copyright law. Copyright, IPR and Moral Rights for the works on this site are retained by the individual authors and/or other copyright owners. Terms and conditions for use of this material are defined in the policies page.

\section{CLoK}

Central Lancashire online Knowledge www.clok.uclan.ac.uk

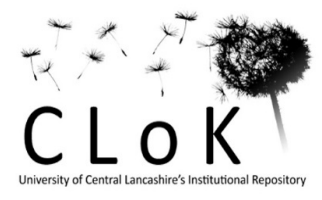




\title{
Children's participation as a struggle for recognition
}

\author{
Nigel Thomas
}

\section{University of Central Lancashire, UK}

\begin{abstract}
Recent attempts to theorise children's participation have drawn on a wide range of ideas, concepts and models from political and social theory. The aim of this paper is to explore the specific usefulness of Honneth's theory of a 'struggle for recognition' in thinking about this area of social practice. The paper identifies what is distinctive about Honneth's theory of recognition, and how it differs from other theories of recognition. It then considers the relevance of Honneth's conceptual framework to the social position of children, including those who may be involved in a variety of 'participatory' activities. It looks at how useful Honneth's ideas are in direct engagement with young people's praxis, drawing on ethnographic research with members of a children and young people's forum. The paper concludes by reflecting on the implications of this theoretical approach and the further questions which it opens up for theories of participation and of adult-child relations more generally.
\end{abstract}

\section{Keywords}

Children, participation, recognition, Honneth, rights 


\section{Children's participation as a struggle for recognition}

\section{Introduction}

Since around 2006 a growing number of scholars have been attempting to construct a more sophisticated theory of children's participation ${ }^{1}$. Before this, the dominant conceptual frameworks had tended to be endogenous to the field, in the sense that, with a few exceptions, they emerged directly from reflection on practice, and also had tended to be classificatory rather than explanatory. Examples include the models developed by Hart (1992, 1997), Franklin (1997), Treseder (1997), Shier (2001), Lansdown (2001), Matthews (2003) and West (2004). Some of these models have been very useful to practitioners in thinking about their work, as indeed have theories of children's rights, and also to some extent the work of Freire (1972). More recent contributions have drawn more widely on exogenous political and social theory. Sources of ideas have included theories of deliberative democracy, theories of governance, spatial theory and theories of social change; also influential have been developments in citizenship theory (Moosa-Mitha, 2005). Percy-Smith (2006, 2010) draws on theories of action research to understand children's participation as collaborative learning. Thomas (2007) has used the political and social theories of Young and Bourdieu to understand children's participation in public life. Cockburn $(2007,2010)$ explores children's participation using theories of deliberative democracy and the 'public sphere'. Mannion $(2007,2010)$ uses theories from geography to reorder participation as a dialogical and spatial practice. O'Toole and Gale (2008) employ theories of governance to understand young people's political engagement, as does Tisdall $(2008,2010)$ in her exploration of children's involvement in policy-making. Graham and Fitzgerald (2010a, 2010b) also focus on the 
process of dialogue, and attempt to analyse what are the conditions for a dialogical approach, drawing in part on theories of recognition.

Most of the contributions referred to above have focused on children's participation in public decision-making of various kinds. There is also some work that attempts to comprehend children's participation in private or individual decision-making - mainly in the care system, in the health service and in families (for example Alderson, 1993, 2010; Thomas, 2002; Butler et al., 2005; Kirby and Laws, 2010); but this is perhaps less developed in theoretical terms, and makes less use of exogenous concepts, with some exceptions.

Together, the above theoretical contributions have the potential to deepen and extend our understanding of what goes on when children and young people 'participate', what are reasonable objectives of work to promote their participation, and what are the constraints and challenges. It is not the aim of this paper to review those contributions in any detail. Rather the purpose is to add a further contribution, by looking closely at a particular social theory that appears to offer something of substance to this wider project. Among the authors mentioned above, recognition theory is referred to by Moosa-Mitha (2005) and Thomas (2007), and is used more extensively by Graham and Fitzgerald (2010a, 2010b). My intention here is to focus on one particular version of recognition theory, namely that developed by Axel Honneth, and to explore its relevance to children's participation.

\section{Theories of recognition}

Contemporary political and social theories of recognition are associated principally with the work of Axel Honneth (1995), Charles Taylor (1994) and Nancy Fraser (1995). All start from the Hegelian idea 'that identity is constructed dialogically, through a process of mutual 
recognition' (Fraser, 2000), and for all three 'misrecognition' is salient. However, the way in which each uses the concept of recognition is significantly different. Taylor's primary concern is with the nature and validity of recognition claims in multicultural societies that include groups with substantially different interests and values, and in particular with the relationship between (i) fundamental rights to equal treatment for all and (ii) particular demands for the recognition of difference. Fraser is critical of some of the greater claims made for the importance of recognition, and is concerned to manage the idea of recognition within a broader emphasis on fairness in the distribution of resources. It may be said that her focus is on status recognition, while Taylor's is on recognition of identity. Honneth's project is more ambitious: to build a theory of social progress that is founded on the concept of recognition as a fundamental element in human interaction and individual and group identity. Not only does he put the concept of recognition at the heart of his social theory; he has also done more than any other author to articulate the concept of recognition in a complex way. It is this articulation, perhaps even more than the overarching theory, that makes his model interesting as a way of thinking about children's participation. ${ }^{2}$

The roots of Honneth's thinking, like Fraser's, are in critical theory, from Adorno and Marcuse to Habermas; his project is to construct a 'social theory with normative content' (Honneth, 1995: xii). The origins of his theory of recognition, as with Taylor's, are in the ideas of Hegel; but, unlike Taylor, Honneth focuses on the early writings of Hegel, the 'Jena period' when Hegel was convinced, as Honneth puts it,

that a struggle among subjects for the mutual recognition of their identity generated inner-societal presure toward the practical, political establishment of institutions that would guarantee freedom. It is individuals' claim to the intersubjective recognition of their identity that is built into social life from the very beginning, as a moral tension, transcends the level of social progress institutionalized thus far, and so gradually leads 
- via the negative path of recurring stages of conflict - to a state of communicatively lived freedom.

(Honneth, 1995: 5)

Honneth's contention is that Hegel moved away from that vision in the development of his later theory, but that it deserves to be resurrected. What Hegel was working towards, but did not complete, was a 'stage theory' that involved three distinct modes and three distinct objects of recognition, as follows:

in the affective relationship of recognition found in the family, human individuals are recognized as concrete creatures of need; in the cognitive-formal relationship of recognition found in the law, they are recognized as abstract legal persons; and finally, in the emotionally enlightened relationship of recognition found in the State, they are recognized as concrete universals, that is, as subjects who are socialized in their particularity.

(Honneth, 1995: 25)

It is this model that Honneth seeks to articulate. Because Hegel's ideas lacked an empirical base, Honneth turned to the social psychology of George Herbert Mead, specifically to Mead's conception of intersubjective recognition as the foundation for our sense of self. Honneth also draws on ideas from Marx, Sorel and Sartre, particularly in examining how the theory may be applied to social movements; but it is the combination of Hegel's overarching theory of society and Mead's close study of intersubjective relationships that underpins his theory of the 'struggle for recognition' as lying at the heart of individual development and of social progress.

Honneth's theory of recognition has been subjected to a number of criticisms, most of which are reviewed by Thompson (2006). These centre mainly on its claim to be an overarching 
theory: Fraser in particular argues that to focus on recognition as the sole motor of social conflict and change is to ignore the central importance of social justice and the distribution of resources. Honneth's view is that the struggles over redistribution can be understood as struggles over recognition and misrecognition; for Fraser redistribution is independent of recognition and is at least as important, and arguably more so (see Fraser and Honneth, 2003). Fraser's conception of recognition, like Taylor's, appears to be centrally about difference. Honneth's version seems equally concerned with commonality, and this is another reason why it may be of particular help in understanding children's participation.

\section{'Love, rights and solidarity'}

Throughout the development of his theory, Honneth maintains the threefold conceptualisation of intersubjective recognition which he originally took from Hegel, for which he found empirical support in Mead, and which he refers to in summary as 'love, rights and solidarity'.

By love he means 'primary relationships insofar as they - on the model of friendships, parentchild relationships, as well as erotic relationships between lovers - are constituted by strong emotional attachments among a small number of people' (Honneth, 1995: 95). For him, these relationships are the site of complex emotional interactions, of which the most significant are affection, attachment, trust, and the struggle to achieve a balance between symbiosis and selfassertion. (He does not use the word 'attachment', drawing on Winnicott rather than Bowlby for his account of primary dyadic relationships.) Many things can go wrong in such primary relationships; but the outcome, when they are successful, is a mutual recognition of independence 'supported by an affective confidence in the continuity of shared concern' (1995: 107). As Honneth acknowledges, 'positive feelings about other people are not matters of choice' and so love 'will always have an element of moral particularism to it'. 
Nonetheless, he argues that Hegel was 'right to discern within it the structural core to all ethical life':

For it is only this symbiotically nourished bond, which emerges through mutually desired demarcation, that produces the degree of basic individual self-confidence indispensable for autonomous participation in public life.

(1995: 107).

By rights Honneth refers to the respect for persons implied in modern legal relations. This second mode of recognition, unlike the first, has to be understood historically. In pre-modern societies legal recognition was tied to social norms and roles based on individuals' allotted place in society, and therefore is not clearly distinguished from esteem (see below); this is reflected in Mead's conceptualisation, which Honneth seeks to move beyond. The modern transformation of legal recognition is a continuing one, and Honneth broadly accepts Marshall's tripartite account of this in terms of civil, political and social rights. The first step, however, is that 'subjects reciprocally recognize each other with regard to their status as morally responsible' (Honneth, 1995: 110). Honneth links this to a Kantian concept of rational autonomy that immediately raises questions about who is included; questions that, I argue later, he does not fully address. What he does suggest is that 'the essential indeterminacy as to what constitutes the status of a responsible person leads to a structural openness on the part of modern law to a gradual increase in inclusivity and precision' (ibid.). This tends to produce both an extension of the classes of people to whom basic human rights are extended, and an extension of the types of rights to which they are entitled, as Marshall showed. ${ }^{3}$ Honneth's contribution is to link this with social respect, and with self-respect, which he argues is dependent on the ability to claim ones rights through a legal process. Empirical support for this is to be found in the negative; for example, in experiences of the 
civil rights movement, where subjects 'talk of how the endurance of legal under-privileging necessarily leads to a crippling feeling of social shame, from which one can be liberated only through active protest and resistance' (1995: 121; see also Fanon, 1963).

By solidarity Honneth means the outcome of 'social relations of symmetrical esteem'. This is perhaps the most difficult of the three modes to grasp in simple terms, because it is the most subject to contestation of various kinds; and this paragraph does not do full justice to Honneth's nuanced historical account (1995: 121-130). The starting point of his analysis is the separation of respect from esteem: the universalism of modern legal relations which underpins the former can only be achieved by 'an uncoupling of legal recognition from the forms of social regard in which subjects are recognized according to the socially defined worth of their concrete characteristics' (121). The question then is what becomes of 'the socially defined worth of their concrete characteristics'. Honneth's predecessors saw this in terms of a single type of value-community (Hegel's conception of 'ethical life' and Mead's democratic division of labour). Honneth uses a broader conception of the values and goals that 'taken together, comprise the cultural self-understanding of a society' (122). This understanding is historically variable, and the forms that esteem can take therefore depend in part on 'the degree of pluralization of the socially defined value-horizon' (ibid.). Specifically, Honneth argues that the move to a social order in which values (a) are not tied to one's place in society and (b) are subject to individual determination, creates a space in which people's sense of being 'valuable' depends on being 'recognized for accomplishments that they precisely do not share in an undifferentiated manner with others' (125). However, he is also clear that 'the worth accorded to various forms of self-realization and even the manner in which the relevant traits and abilities are defined fundamentally depend on the dominant interpretations of societal goals in each historical case' (126). This means that: 
In modern societies, relations of social esteem are subject to a permanent struggle, in which different groups attempt, by means of symbolic force and with reference to general goals, to raise the value of the abilities associated with their way of life.

Solidarity, then, is more readily achieved within a group with shared goals; the greater challenge is to extend that solidarity, based as it must be on a reciprocal recognition of each other's particular worth, to a wider society. This is close to the territory in which Taylor (1994) is engaged.

\section{Children's claim to recognition}

Honneth's theory of recognition is both a theory of individual development in a social context, and a theory of social change in a historical context. These are both major claims, but their general validity is not the primary concern of this paper; neither is it to evaluate the evidential basis for his theoretical model, although that is clearly an important task, in which Honneth and his critics have been, and still are, engaged. Rather, my object here is to explore the utility of Honneth's theory of recognition for understanding children's participation. I do so on the basis that it is a well-articulated theoretical framework, with intuitive credibility, which brings to the forefront some important distinctions between different aspects of relationship and interaction, in the form of the three modes of recognition. Although the theory is a developmental and historical one, and the modes are also expressed as stages (if mainly cumulative rather than successive), a degree of synchronicity in its application is also permissible, even necessary. We do not cease to need recognition as love, and the point at which we begin to need respect and esteem may be rather earlier in life than Honneth sometimes implies, as I argue below. On this basis, the model can in principle be used to interrogate any social setting - for example a workplace, a festival, a parliament, a nursery, a 
war - since all three modes of recognition will always be more or less present or absent, and the ways in which they are or are not expressed may or may not be problematic. ${ }^{4}$

Honneth does not talk about children except in the context of primary relationships of love and care. This is not surprising: the default position of most social and political theory, even now, is either to disregard children entirely or to regard them only as adults in waiting, and Honneth generally opts for the latter:

Just as, in the case of love, children acquire, via the continuous experience of 'maternal' care, the basic self-confidence to assert their needs in an unforced manner, adult subjects acquire, via the experience of legal recognition, the possibility of seeing their actions as the universally respected expression of their own autonomy.

The exclusion of children from universal human rights is taken as read, which means that the question of their status is not made explicit. This is in the face of Honneth's own assertion that

It must always be asked of a universally valid right - in light of empirical descriptions of the situation - what the circle of human subjects is, within which, because they belong to the class of morally responsible persons, the rights are supposed to be applicable.

My starting point here, unlike Honneth's, is: (i) that children do belong to the class of morally responsible persons, are therefore rights-bearers and entitled to respect; (ii) that children are people with talents and capabilities, who contribute in a variety of ways to society and culture and are therefore deserving of esteem. Those propositions are by now axiomatic in their 
respective fields (children's rights and the sociology of childhood), but have penetrated only to a very limited extent into wider political and social theory.

Once these points are accepted, it then becomes possible to analyse children's place in society using the concepts provided by Honneth's recognition theory: to ask when, where and how they achieve reciprocal recognition (i) as love, (ii) as respect and (iii) as esteem. In other words, the model invites us to look at children not only as recipients of care and affection, but also as givers of care and affection, and as rights-bearers and rights-respecters, and as potential, if not actual, members of a community of solidarity based on shared values and reciprocal esteem. In the rest of this paper, the specfic field of 'children's participation' is the focus for that enquiry. The question is: does Honneth's theory of recognition, and in particular his conception of a struggle for recognition, offer a useful way of thinking about children's participation?

\section{An example of participation in practice}

The example used here is drawn from ethnographic research conducted between 2004 and 2007 in a Welsh county (Author reference). When 'Funky Dragon', the Children and Young People's Assembly for Wales, was established in 2000, the Welsh Assembly Government asked each local authority to set up a children and young people's forum, to provide representatives for Funky Dragon and as 'a way of making local organisations listen to children' (Welsh Assembly Government, 2004). In the area where the research was done, there is a Youth Assembly for the whole county, linked to forums in different localities and special interest groups. A voluntary organisation, funded by the local authority, employs workers who support the Assembly and the forums. 
For the field research I attended 17 meetings of the Assembly and the forums, observing and making notes, and having informal conversations with those attending. I also conducted two interviews with small groups of young people and one with a youth worker. What follows is based mainly on my notes of the observations and transcripts of the interviews, supported by reflective comments recorded at the time and on successive re-readings which led to further thematic analysis. The research was undertaken by agreement with the voluntary organisation responsible for the work, and with the continuing permission of the young people taking part. It was approved by the appropriate university research ethics committee.

Group members had varying degrees of prior knowledge of each other. Because of turnover in membership, each meeting might have one or two relative newcomers; however, most members (young people and adults) knew each other fairly well and had clear ideas of each other's personality and characteristics, which they employed regularly in meetings and discussions. There were affectionate bonds between members of the group, with frequent hugs at the beginning of residential meetings. The leading adult worker appeared to have strong and warm relationships with most members of the group, and used her individual knowledge of their personalities and preferences to select members for tasks.

This worker defined the purpose of the group thus:

The main one is to get their voices and their opinion heard and involved in decisionmaking, at the local level, and county level, and in some cases at national level. I would say they think the main purpose is for them to have a voice, but it also gives them an opportunity to get together and develop relationships, and they have developed really strong friendships. And that goes hand in hand with community activity, getting stuff done in their communities; which some of the forums have done, but not as much as I'd like to be done and to be recognised. 
This could be summarised as (i) voice in public affairs; (ii) friendship and solidarity; (iii) community action.

In an interview with three experienced young members this was expressed slightly differently

Member A: well, to get the young people's voices heard - let the young people have more of an existence, I'd say

Member B: and like, the young people that sit on the youth assembly, they get provided with training which then they can take to their forums and teach to other people; and then eventually I mean, you go places now and you see the techniques being put in everywhere, this is like techniques that everyone's using, so it's all about training as many young people so that they've got the confidence to do things

Member A: I think getting involved in your community is really important - I love the fact that I'm slap bang in the middle of my community, you know, and sat on various committees there, and it's just, it's really good, d'you know, and then you're walking down the street, and you see a few adults, like, and 'all right A, how are you?' and I'm like 'oh my god, you know me now!'

This could be summarised as (i) voice and recognition; (ii) developing skills and capacity; (iii) becoming part of the community. The young people talked more about friendship elsewhere in the interview, and the adult worker talked about capacity-building later in her interview, but as a means to achieve the other purposes rather than as a purpose in itself.

From observation of meetings it was possible to distinguish all the above purposes in relation to different activities - expression of 'voice', development of skills, strengthening social relationships, or taking part in action. One of the most striking distinctions was between activities whose purpose was internal to the group, in that they had been chosen and planned 
by group members in order to promote their objectives, and those whose purpose was external, in that they had been requested or solicited by an outside agency. The weight of expectations from outside agencies was frequently evident in meetings, and surfaced in interviews with young people.

The youth workers employed to facilitate the young people's meetings had key roles: it was they who enabled the groups to meet, supported individuals to attend meetings and take on responsibilities, encouraged the group to reflect on its work and plan its activities, and channelled information between the young people and key agencies. Other adults of significance for the young people were the agency staff referred to above, and also visitors to the meetings, who came from a range of organisations and for a variety of purposes. Although the dominant visible relationship was with the staff working directly with the young people, the influence of certain 'off stage' players, such as the leadership of the local children and young people's partnership, was considerable.

Much of the more formal business at meetings was in effect led by adults, although young people might be nominally in charge. Agendas appeared to be largely produced by adults, but both workers and young people told me that they made roughly equal contributions to determining the agendas. The question of leadership was a live one in the group during the period of the research, as the following extracts from a group discussion (without adult workers present) reveal:

Member C: 'A lot of people I talk to think that adults should make decisions for us.' Member D: 'A lot of them don't realise that adults can get it totally wrong.'

Member D: 'I could lead the forum and the members would probably let me - but my youth worker has been used to being on top for so long.' 
Member B: 'Use the training you've had on policy making - why not say you want to sit down and make a policy on how the forum should run?'

Member C: 'That piece of work this morning, even though it was hard, it was good that we didn't have the staff helping us all the time.'

Some of what took place in the meetings can be interpreted in terms of struggles for control. I noticed examples, both of adults taking over items of business from young people, and of young people seeking to wrest control of proceedings from the adults - or of declining to do so when the opportunity might have arisen. In an early formal session, one of the young people was scheduled to report back from a working group planning a conference; but very soon the worker in charge had taken over and was explaining the plans produced by the group in great detail, although not only the young person who had started to report back but also another member of the working group was present round the table, and both appeared ready and able to give the report. Later in the same meeting the worker was drawing proceedings to a close, when the (relatively young) group member who was designated as Chairperson for the occasion asserted his own right to close the meeting.

\section{Participation and modes of recognition}

Looking at the processes by which young people become members of participatory groups such as those studied here, and how they go on to participate in different ways and discover new capacities and roles for themselves, one sees how Honneth's categories of recognition are relevant at each stage. Love and friendship, offered by the workers to the young people from the moment they join and also by the young people to each other, seem to be foundational for all the other activity in which they engage. It is clear that without the 
encouragement and affection shown by the workers to the young people - and to them as unique individuals - many of them might have dropped out at an early stage, or at least not have had the confidence to become fully involved. The young people were also clear that the friendship they received from each other was a primary reason for wanting to be part of the group and to take part in all the activities - some of which were not especially rewarding in themselves. When asked at one meeting what made them stick with the group, all the young people replied 'friends'.

The place of rights in the project is somewhat more ambiguous. The young people did not often talk about rights explicitly, although they did frequently talk about 'getting their voices heard' in a way that implied a sense of entitlement. The leading worker appeared to see this as a failing:

If I had my time over again I'd start it differently - I'd initially start from their rights, children's rights, and start from the UN Convention - so they'd know, they'd have a base understanding of why it's happening.

At a political level rights may be seen as underpinning the whole project, since it is the Welsh Assembly Government's espousal of children's rights that led them to introduce an expectation that there should be local and national representation of young people's voices, and that has spurred local authorities and other agencies to take these organisations seriously. In this context it is interesting that the young people did not 'bang on' about their rights; it is possible that they simply take it for granted that these are understood and recognised.

In the conversations I had with them the young people seemed more exercised by the issue of esteem. The comments by Member A quoted above (pp. 9-10) led to the following exchange: 
Member E: It's like you're walking with your friends and it's like 'I don't like you at the moment' 'Why?' 'Cos we walk through town and everyone seems to know you.' Member A: I love it.

Member B: It's really nice, and just, you know like, all of the adults that we work with like, in Forums and stuff, that if you do bump into them they ask you how things are and what have you been up to, and it's just all about, we've built a lot of relationships up with these adults, and they treat us like equals. They don't patronise us. They don't talk to us like we're little kids.

Member A: I think some... do

Member B: Some do

Member A: But they're the ones that don't say 'hi' in the street!

Member B: But a lot of them now they accept us and they accept us as equals, and they want to hear our opinion, because they've realised that it's actually valuable?

Member A: Oh I love it, I love being asked for my opinion

The young people were particularly proud of the contributions they had been able to make to their local communities - more, perhaps, than their contacts with important people at a national level, although these were sometimes a cause of excitement too.

Some time after the research finished I happened to meet two members of the group, who had since left. Together we were reflecting on our experiences of the meetings. I explained to them, in straightforward terms, how I was using recognition theory to try to understand what went on. They agreed that love and friendship had been essential to them taking part in the process, and that esteem was what the group had been aiming for. Again, they had little to say about rights. In some ways rights are the missing link in the whole process. There were many 
instances where the young people did not appear to be wholly respected as equals, either by the workers or by outside organisations with whom they were dealing, and they seemed unsure how, or how far, to challenge that. If Honneth's model is right, then one might expect that they will continue to have limited success in being recognised for the value of their contribution until they first engage in a more effective struggle for equal respect.

\section{Discussion}

The analysis offered in this example is very preliminary, and more work is needed to explore more fully how Honneth's theory of recognition can help in understanding children's participation. It will be important to move on, from identifying points where his categories apply, to showing how this can be used to produce analysis and critique. However, if the task of theorising children's participation is conceptualised as (i) analysing what is meant by participation, (ii) understanding what happens when children participate, and (iii) a normative account in terms of the ethical purposes of the activity, then I argue that Honneth's theory has a contribution to make to all of these.

In terms of understanding what happens, settings and processes of participation can be evaluated according to how well they satisfy criteria of 'love, rights and solidarity'. My argument is that all three modes of recognition are essential for children's full participation. Children do not engage fully if they do not feel a sense of warmth and affection; they cannot participate equally if they are not respected as rights-holders; and they will not have a real impact unless there is mutual esteem and solidarity, and a sense of shared purpose.

Honneth's theory should also help us to see that reciprocal recognition is not merely reducible to dialogue. Dialogue is critically important, as Mannion $(2007,2010)$ and Graham 
and Fitzgerald (2010a, 2010b) have shown. However, participation is not just about talk, or 'voice', but about shared action too (Percy-Smith, 2006, 2010; Percy-Smith and Thomas, 2010). Dewey's conception of democracy as reflexive cooperation is highly relevant here, as Honneth (1998) has argued elsewhere. On this view, shared action and the societal division of labour are an essential underpinning for collective deliberation.

An important recent critique of recognition theory is by McNay (2008), who argues that it takes insufficient account of power. Although her critique is not solely directed at Honneth, it must be acknowledged that there is a tendency in his account to focus on the successful achievement of modes of recognition. However, the idea of a 'struggle for recognition', together with the crucial concept of misrecognition (about which, admittedly, not enough has been said here), certainly offers a space in which power, and differentials in power, can be identified, studied and contested. One problem with children's participation, both in practice and in theory, is that it is too often described in non-conflictual terms: as if all that is required is for children and adults to sit down and talk together, and all will be well. Mouffe (2000) reminds us that conflict and the agonistic are an inescapable part of democracy. Children's political disenfranchisement is a serious handicap in their ability to engage on equal terms in these processes, which is why the claim to recognition as respect, in this case for children's status as full bearers of rights, is so important.

\section{Conclusion}

The aim of this paper has been to explore how the model of recognition proposed by Honneth has the potential to be used as an analytic tool for understanding children's participation. Because it provides a way of thinking about the personal along with the public, the emotional along with the rational, it offers the possibility of escaping the limitations of other theoretical 
approaches which focus on one dimension, such as deliberation or influence. Children's participation is a term that can include a wide range of different phenomena in different social settings: private and public, structured and unstructured, formal and informal. What all these phenomena have in common is that they tend to encounter fundamental questions about children's place in society, and about intergenerational relations. To make Honneth's model fit for purpose in tackling these questions, it has first to be critiqued for its inherent bias (common to much 'mainstream' political and social theory) against children's agency, sociality and citizenship. Once this is achieved, we have a theoretical framework that can be extremely helpful, both in the analysis of particular examples of children's participation and in thinking more seriously about the meaning of children's participation in general.

\section{References}

Alderson, Priscilla (1993) Children's Consent to Surgery. Buckingham: Open University Press.

Alderson, Priscilla (2010) 'Younger children's individual participation in matters that affect them', in Percy- Smith, B. and Thomas, N. (eds) A Handbook of Children and Young People's Participation: perspectives from theory and practice. Abingdon: Routledge.

Butler, Ian, Robinson, Margaret and Scanlan, Lesley (2005) Children and Decision Making. London: National Children's Bureau.

Cockburn, Tom (2007) 'Partners in Power: A radically pluralistic form of participative democracy for children and young people', Children \& Society 21(6), 446-457. 
Cockburn, Tom (2010) 'Children and deliberative democracy', in Percy-Smith, B. and Thomas, N. (eds) A Handbook of Children and Young People's Participation: perspectives from theory and practice. Abingdon: Routledge.

Fanon, Frantz (1963) The Wretched of the Earth, Harmondsworth: Penguin.

Franklin, Barbara (1997) 'The Ladder of Participation in Matters Concerning Children' in Boyden, J. and Ennew, J. Children in Focus: a Manual for Participatory Research with Children. Stockholm: Grafisk Press.

Fraser, Nancy (1995) 'From Redistribution to Recognition: dilemmas of justice in a “postsocialist” age', New Left Review 212, 68-93.

Fraser, Nancy and Honneth, Axel (2003) Redistribution or Recognition: A PoliticalPhilosophical Exchange. London: Verso.

Freire, Paolo (1972) Pedagogy of the Oppressed. Harmondsworth: Penguin.

Graham, Ann and Fitzgerald, Robyn (2010a) ‘Children's participation as a struggle over recognition: exploring the promise of dialogue'in Percy-Smith, B. and Thomas, N. (eds) $A$ Handbook of Children and Young People's Participation: perspectives from theory and practice. Abingdon: Routledge.

Graham, Ann and Fitzgerald, Robyn (2010b) 'Progressing children's participation: Exploring the potential of a dialogical turn', Childhood 17(3), 343-359.

Hart, Roger (1992) Children's Participation: from tokenism to citizenship. Florence: UNICEF.

Hart, Roger (1997) Children's participation: the theory and practice of involving young citizens in community development and environmental care. London: Earthscan. 
Honneth, Axel (1995) The Struggle for Recognition: The Moral Grammar of Social Conflicts. Cambridge: Polity Press.

Honneth, Axel (1998) 'Democracy as Reflexive Cooperation: John Dewey and the Theory of Democracy Today', Political Theory 26(6), 763-783; reprinted in Honneth, Axel (2007) Disrespect: The Normative Foundations of Critical Theory. Cambridge: Polity Press.

Kirby, Perpetua and Laws, Sophie (2010) ‘Advocacy for children in Family Group Conferences: reflections on personal and public decision-making', in Percy-Smith, B. and Thomas, N. (eds) A Handbook of Children and Young People's Participation: perspectives from theory and practice. Abingdon: Routledge.

Lansdown, Gerison (2001) Promoting Children's Participation in Democratic DecisionMaking. Florence: UNICEF Innocenti Research Centre.

Mannion, Greg (2007) 'Going spatial, going relational: Why "listening to children” and children's participation needs reframing', Discourse 28(3), 405-420.

Mannion, Greg (2010) 'After participation: the socio-spatial performance of intergenerational becoming', in Percy-Smith, B. and Thomas, N. (eds) A Handbook of Children and Young People's Participation: perspectives from theory and practice. Abingdon: Routledge.

Marshall, Thomas (1963) 'Citizenship and social class' in Sociology at the Crossroads, London: Heinemann.

Matthews, Hugh (2003) 'Children and regeneration: setting an agenda for community participation and integration', Children \& Society 17(4), 264-276.

McNay, Lois (2008) Against Recognition. Cambridge: Polity Press.

Mead, George Herbert (1934) Mind, Self and Society. Chicago: University of Chicago Press. 
Moosa-Mitha, Mehmoona (2005) 'A difference-centred alternative to theorization of children's citizenship rights', Citizenship Studies 9(4), 369-388.

Mouffe, Chantal (2000) The Democratic Paradox. London: Verso.

O’Toole, Therese and Gale, Richard (2008) 'Learning from political sociology: structure, agency and inclusive governance', International Journal of Children's Rights 16(3), 369378.

Percy-Smith, Barry (2006) 'From consultation to social learning in community participation with young people', Children Youth and Environments 16(2), 153-179.

Percy-Smith, Barry (2010) Councils, consultation and community: Rethinking the spaces for children and young people's participation, Children's Geographies 8(2), 107-122.

Percy-Smith, Barry and Thomas, Nigel (2010) 'Conclusion: Emerging themes and new directions' in Percy-Smith, B. and Thomas, N. (eds) A Handbook of Children and Young People's Participation: perspectives from theory and practice. Abingdon: Routledge.

Shier, Harry (2001) 'Pathways to Participation: Openings, Opportunities and Obligations', Children \& Society 15(2), 107-117.

Taylor, Charles (1994) 'The politics of recognition', in Gutmann (ed.)

Multiculturalism:Examining the Politics of Recognition. Princeton University Press.

Thomas, Nigel (2002) Children, Family and the State: Decision-making and Child Participation. Bristol: Policy Press.

Thomas, Nigel (2007) ‘Towards a theory of children's participation', International Journal of Children's Rights 15(2), 199-218. 
Thompson, Simon (2006) The Political Theory of Recognition: A Critical Introduction.

Cambridge: Polity Press.

Tisdall, Kay (2008) 'Is the honeymoon over? Children and young people's participation in public decision-making', International Journal of Children's Rights 16(3), 419-29.

Tisdall, Kay (2010) 'Governance and participation' in Percy-Smith, B. and Thomas, N. (eds) A Handbook of Children and Young People's Participation: perspectives from theory and practice. Abingdon: Routledge.

Treseder, Phil (1997) Empowering Children and Young People. London: Children's Rights

Office and Save the Children.

Welsh Assembly Government (2004) Children and Young People: Rights to Action. Cardiff: Welsh Assembly Government.

West, Andy (2004) 'Children and Participation: Meaning, Motives and Purpose' in Crimmens, D. and West, A. (eds) Having Their Say: Young People and Participation: European Experiences. Lyme Regis: Russell House.

\footnotetext{
${ }^{1}$ In this paper the term 'children' is mainly used to apply to all people under the age of 18 . The term 'children and young people' is in some ways preferable, but on this occasion it seemed simpler to use the single word. In the section discussing the empirical research with a group of young people, the latter phrase is used, since that was the term accepted in the group.

${ }^{2}$ For an admirably thorough, incisive and balanced discussion of the three theories of recognition, see Thompson (2006).

3 'The institutionalization of bourgeois liberties initiated, as it were, a permanent process of innovation that gave rise to at least two new classes of individual rights, because what was demonstrated again and again in subsequent history, under pressure from disadvantaged groups, was that not all of the appropriate preconditions were present for equal participation in a rational agreement: in order to be involved as morally responsible persons, individuals need not only legal protection from interference in their sphere of liberty, but also the legally assured opportunity for
} 
participation in the public process of will-formation, a process that they can only actually take advantage of, however, if they also have a certain social standard of living.' (Honneth, 1995: 117).

${ }^{4}$ For example, to assume that recognition in the form of mutual affection, even love, is of no relevance in the workplace could be a mistake, and certainly ought to be tested empirically. 